Portland State University

PDXScholar

\title{
Teaching an International Bestseller: Reflections on Encouraging Caring Global Citizenship
}

Evguenia Davidova

Portland State University, evguenia@pdx.edu

Follow this and additional works at: https://pdxscholar.library.pdx.edu/is_fac

Part of the Curriculum and Instruction Commons, and the Curriculum and Social Inquiry Commons Let us know how access to this document benefits you.

Citation Details

Davidova, E. (2021). Teaching an International Bestseller: Reflections on Encouraging Caring Global Citizenship. The Journal of General Education, 69(1-2), 21-29. doi:10.5325/jgeneeduc.69.1-2.0021

This Article is brought to you for free and open access. It has been accepted for inclusion in International \& Global Studies Faculty Publications and Presentations by an authorized administrator of PDXScholar. Please contact us if we can make this document more accessible: pdxscholar@pdx.edu. 


\title{
Teaching an International Bestseller: Reflections on Encouraging Caring Global Citizenship
}

\author{
EVGUENIA DAVIDOVA
}

ABSTRACT | This article discusses an integrative model of gradual scaffolding of curricular and pedagogical strategies, based on the theoretical framework of a "caring global citizenship." It provides concrete practices for internationalization of general education that could be implemented in a wide variety of institutional settings. Such a model addresses ethnocentrism by expanding students' knowledge and perspectives on societies influenced by American politics, and fosters empathy as both value and skill.

\author{
KEYWORDS | global \\ citizenship, \\ interdisciplinary \\ education, \\ intercultural skills, \\ internationalization, \\ empathy
}

Traditionally, internationalization of higher education comprises foreign language requirements, study abroad, enrollment of international students, support for faculty travel abroad, internationalization of curriculum, and sponsorship of international campus events. After 9/11, the Commission on the Abraham Lincoln Study Abroad Fellowship Program of 2005 enhanced the first two elements by urging American universities to send more students abroad. The rationale was to expose them to other cultures and languages (Mills, 2014, p. 233). Yet other researchers acknowledged also the development of attitudes, skills, and competencies at home. For example, the model for internationalization of undergraduate education suggested by Cornwell and Stoddard (1999, p. 21) put an emphasis on understanding diverse cultures and global processes; developing intercultural skills, and preparing for "citizenship, both local and global." Recent studies tend to unite the two approaches: study abroad (internationalization) and study at home (global citizenship). Moreover, new technology not only allows learning about the interconnectedness of the world but also brings new rights and responsibilities. However, the practical difficulty for teachers is how to "discourage inappropriate entitlement, 
and encourage empathy, service to others, and decentered perspectives" (Watters, 2013, p. 52). In order to address this tension, I borrow from Matthew Sparke the term "caring global citizen" (2013, p. 413), which implies college students who are equipped with critical knowledge of global inequities and the forces that produce them; have civic values that acknowledge agency in people in other countries; and question media stereotypes and their own assumptions.

This article analyzes the findings of a pedagogical project conducted in three consecutive years (2017-19) at freshman level that challenges a students' sense of entitlement ${ }^{1}$ and proposes an "immersion" model that comprises building the imaginative capacity of students to comprehend daily lives in different cultural contexts. A note of caution is in order here: "immersion" is qualified in quotation marks to acknowledge the limitation of the concept since most learning happens in the classroom without contacts with people and communities. The model, though, offers an approach that increases student commitment to learning and intercultural and social awareness by incorporating skills and life experiences into classroom activities. It is the synthesis of gradual scaffolding of curricular and pedagogical strategies, based on the theoretical framework of a "caring global citizenship," which provides concrete practices for internationalization of general education that could be implemented in a wide variety of institutional settings. This article emphasizes discussion of qualitative data acquired from student work. In what follows, I provide a brief institutional background, a description of the integrative model, the pedagogical approaches and student response, and suggestions for broader applications.

\section{Institutional and Interdisciplinary Background}

University Studies, Portland State University's General Education program, was founded in 1994; it comprises a four-year interdisciplinary integrated curriculum (White, 1994). The courses provide students with learning experiences based on four goals: inquiry and critical thinking; communication; diversity, equity, and social justice; and ethics, agency, and community. The freshman inquiry is a yearlong sequence of three terms with team-based teaching. In addition, each faculty member is paired with an upper division student who leads three supplementing mentor inquiry sessions, which provide hands-on activities. The main session's pedagogy is interactive and includes various teaching methods encouraging intellectual growth and promoting civic learning.

Each year-long freshman inquiry course has a broad theme, addressed from multidisciplinary perspectives. The course "Power and Imagination," for example, explores issues of institutional power, colonialism and imperialism, globalization, social justice, and empowerment. Each term has a built-in set of activities and readings that are meant to expose students to cultures other than 
their own, placed within the larger context of globalization. For example, in the fall quarter, the focus is on institutions that produce and maintain power, and as part of the module on education, the students read a chapter from Paulo Freire's classic Pedagogy of the Oppressed (1970). The book introduces a critical view on school as a hierarchical institution that mirrors other power relations in society. The complex ramifications of late capitalism are explored in the winter term, with a focus on colonial legacies, migrations, and a requirement for a "commodity chain" research paper. After setting the stage for examination of structural inequities, the students are walked through various forms of empowerment from below.

It is within the context of such responses to globalization that I am Malala: The Girl Who Stood Up for Education and Was Shot by the Taliban (Yousafzai with Lamb, 2013), a book with rich pedagogical possibilities and whose author is the youngest holder of the Nobel Peace Prize (2014), seemed a very pertinent read for the third quarter. It not only provides students with a gendered lens to analyze global inequalities but also offers both a social and a cultural canvas of a country (Pakistan) undergoing rapid change. As the third term is designed to synthesize skills and perspectives from the previous two, I provided an anthropological point of view by connecting I am Malala to Clifford Geertz's (2005) essay "Deep Play: Notes on the Balinese Cockfight," a text the students studied during their first term. I encouraged them to seek an understanding of different cultures from locals' standpoint and to look for similarities within their own societies.

Whereas Freire illustrates the empowering role of education for peasants, I Am Malala elucidates the same for women across the Global South. Both texts reveal the intentional perpetuation of illiteracy for political purposes and encourage readers to appreciate schooling and critical thinking as tools for the "emergence of consciousness and critical intervention in reality" (Freire, 1970, p. 68), which is exactly what Malala did. ${ }^{2}$

\section{Model for Enhancing International Understanding and Major Themes Discussed in I Am Malala}

This model presents a long-term synthesis of curricular choices with an emphasis on texts that derive from international authors (predominantly from the Global South); pedagogical strategies such as scaffolding of activities and diminishing of the structure of the assignments that accompany them. At the same time, every term, there is a deepening of the level of metacognitive tasks (students' reflection on their learning process) and of the discussions about the complexity of other cultures and the limited way we "know" about them through media. This integrative model is grounded on the pedagogical goal of 
creating a safe class environment with an expanding level of spontaneity and creativity. Last, an example of synthesis that is happening toward the end of the year includes an engaging book that not only challenges ethnocentrism but also builds intercultural skills through a creative "immersion" assignment. Hence, it is the entirety of all pedagogical interventions that were oriented toward producing a "caring global citizenship."

The genre of I Am Malala-a memoir-exposes students to quotidian forms of asymmetrical globalization. One has to walk them through the book to tease out the main themes. First, it sheds light on global terrorism. Malala comes from the Northwest Frontier Province at the border with Afghanistan, from the town of Mingora in the Swat Valley. This is the area that the Taliban used to infiltrate Pakistan's territory. The state of Pakistan itself is a postcolonial entity that comprised most Muslim territories after the partition of British India in 1947. The book is also successful in depicting the increased role of the military within the Pakistani political and social fabric during the Cold War and the recent War on Terror. ${ }^{3}$ Although all students are familiar with the Global War on Terror[ism], the book reveals the complexity of the U.S. foreign policy and its devastating impact on local people in Pakistan. Thus, many students had to grapple with the dominant assumptions about Islam and life in the Global South. The deconstruction of such prejudices is, of course, one of the most appealing achievements of the memoir.

The focus on women's education is another strong point that was addressed in other readings throughout the course. In her own words, Malala asked, "How dare the Taliban to take away my basic right to education?" (Yousafzai with Lamb, 2013, p. 142). American freshmen often take the right to education for granted. Therefore, the class explored various types of schools, their curricula, and multiple forces controlling the Pakistani educational system. The book encapsulates the ways that traditions and imported cultural practices co-produce the structures of knowledge in Pakistan. In addition to various differences, the many similarities evoke our common humanity. The tender relations within Malala's nuclear and extended family, her friendships at school, her courage to speak and to stand up against injustice, and her desire to help homeless children, to name just a few examples, are all behaviors that students can relate to and experience in their lives.

\section{Pedagogical Approaches}

From a theoretical and instructional perspective, application of the general theory of social construction of knowledge and active learning strategies were useful for designing the pedagogical strategies (Bonwell and Eison, 1991). The course pedagogy included from the beginning of the school year interactive 
lectures, small group work, and class discussion; all with the intent to foster a participatory learning community. For example, I provided a lecture with some general context about Afghanistan, Pakistan, and the "War on Terror." During the next class, I tried to engage students with inquiry-based concepts and questions with reference to the daily experiences of Malala, her family, and her community. As homework, students had to bring comments on three Pashtun traditions, described in the first section of the book. Most of them wrote in a dichotomous way about ceremonies of birth (and the cultural preference for boys), marriage, and hospitality our class discussions unpacked the commonalities between cultural practices that originally seemed quite different in comparison to other cultures. Next, classroom activity included work in small groups and in the class as a whole on the issue of terrorism; the main question was, "What made the Taliban so successful in conquering the Swat region?" The class also discussed analogies to the self-proclaimed Islamic State.

By gradually preparing the class to understand that the text provides a very complex social and cultural tapestry, the students were introduced to the creative written assignment. It required them to imagine themselves to be someone living in Swat during the last two decades who wants to record and transmit their experience either to their family/community or to an international audience. This assignment necessitated ethnographic and historic research about intergenerational transmission of cultural customs. By trying to create a plausible character (such as pupil, teacher, dancer, vendor, journalist, doctor, politician, police officer, etc.) students had to write a story of a specific event, mentioned in the book, and place it within a broader context. The genre was open: a letter, diary entry, excerpt from a memoir, poem, interview, journalistic article. The important task was to develop empathy for people who live in a precarious environment from which many are forced to emigrate and respect for their courage and agency.

My motivation for this assignment came from Elaine Scarry's comment on the difficulty of imagining the pain of the others, "human capacity to injure other people is very great precisely because our capacity to imagine other people is very small' (1998, p. 45). Because an approach that tries to imagine other peoples' lived experience entails the danger of cultural appropriation, the following strategy was used to caution students. First, after handing out the assignment, there was a class discussion about Scarry's quote and the emotional and intellectual limits of empathy, or the ability to imagine another person's experience. Second, the class also talked about the ethics and power asymmetries in appropriating racial, ethnic, gender, religious, and sexual identity. The latter was linked to another course reading, a chapter from Justice and the Politics of Difference by Iris Young (1990). Third, students were also reminded of the notion of "Orientalism" and (post)colonial representations of non-European 
cultures as inferior; an excerpt of Edward Said's book Orientalism (1979) was examined during the winter term. It seems that such framing of the project, which I did not do during the first year, prepared most students to address the task with openness and respect. Thus, students had a better idea that the assignment required them to do some preliminary research in order to engage with a multiplicity of voices and perspectives.

Exposure to such texts for the sake of enhancing internationalization of the general education curriculum results in critical engagement with new information and introduces students to reflective practices by engaging situational emotions. All the activities were intended to create classroom social situations as intercultural interactions by following two major pedagogical principles: the building of a safe classroom environment and giving more agency to students. The educational value of expanding levels of spontaneity and creativity is fostering critical engagement with the subject matter, as the student responses demonstrated. Although I did not use a rubric that measures empathy, future research would contribute to such evaluation and would broaden the applicability of such approach.

\section{Student Engagement}

Most students enhanced not only their research skills but also gained respect for other cultures: ${ }^{4}$

The book and the paper made me make some extra research in order to get some more background information that the book couldn't give me. Which ties to Inquiry and Critical Thinking because I had to explore and write it from a different perspective and having the correct information to be able to communicate what I was trying to express. For example for the paper I had to research a name that tied with their culture.

Student papers also disclosed high sensitivity to the living conditions of ordinary people and their courage to face adversity in life. The theme that seemed to engage many students emotionally was the anxiety of living in a state of permanent violence caused by the militants, the army, and the government. As the following quotes show, they were fearing not so much for themselves but mostly how to provide protection for their loved ones. For instance, one student expressed such fear imagining his life as a teacher in Mingora: "My family and I are always on the look out, whatever it may be, we are not safe until the morning rises with no signs of explosions or disrupting noises." Another student wrote about the lack of citizens' protection: "Our government doesn't pay attention to us because we are so far from the city center. Every day I put 
on my brave face because I don't want my little brothers to be scared like me." Other papers commented on why poor people were attracted to the Taliban propaganda: "If you don't have power or money to control the people that have power, you are brainwashed and trained to be a soldier and to do the dirty work for others." It seems that these examples and others indicate that students were expressing an imaginative capacity to comprehend daily lives in different contexts and even to move toward an ethical engagement and a desire to resist. The sense of defiance from the perspective of a female student was captured in the following quote: "All across Pakistan the Taliban have been blowing up schools for girls, even though it's dangerous to go, it's the only place we get to leave our lives with the Taliban being an afterthought." A midwife expressed directly her empathy: "It is great knowing that each day I make a difference in someone's life." The same student, who aspires to become a nurse, was critical toward traditional preference for giving birth to boys that pressured future mothers: "It makes me sad to think that so many of these women fearing having a daughter, are also daughters themselves."

Various discussions on daily practices engaged undergraduates in meaningful dialogue with one another and created an intercultural class dynamic. For example, students from the Middle East felt comfortable to share how the book was perceived in their own countries. Other students (mostly the ones who took classes on gender studies) made connections to the status of women in U.S. society and the \#MeToo movement. Many freshmen acknowledged that the written assignment was difficult exactly because they had to imagine living in an environment that was both unfamiliar and familiar.

\section{Broader Applications}

Engaging in pedagogy of "otherness" by integrating approaches from various disciplines in order to explore culture and daily life within a broader international framework opens up new possibilities for producing a "caring global citizenship." While the concept of "global citizenship" is getting wider currency, the emphasis on "caring" is becoming equally significant as a new aspect with high pedagogical potential. The model of scaffolding a long-term structure that combined emotional and intellectual dimensions, pertinent to the way students experience the rapidly globalizing world, encourages them to explore not only their own worlds and cultures, but also their impact on others. In the words of one student:" I think its [sic] very important to think about subjects from different perspectives. I just wish more college classes allowed that kind of thinking. Allowing creative responses can help deepen understanding of topics being taught in class." Hence, the desired orientation of students toward "caring global citizenship" can happen in the classroom, but only through slow and careful 
development of intercultural attitudes and skills. Moreover, such a model can be adapted and implemented within a single class or a cluster of classes.

Using engaging books by international authors, after focused pedagogical preparation, both broadens and deepens internationalization within the general education curriculum. However, more important is designing an integrative model through various curricular and pedagogical interventions that contribute to expanding student awareness of the interconnectedness of local, regional, national, and global issues as well as their own roles in these processes. Furthermore, the "caring global citizenship" model acknowledges, with empathy, that such connectivity is also asymmetrical, and general education in the U.S. usually marginalizes voices for social justice of people from the Global South. An "immersion" project like the one described in this article can help to address ethnocentrism, to expand students' knowledge and perspectives on societies influenced by American politics, to respect ordinary people's agency, and to foster empathy as both value and skill.

EVGUENIA DAVIDOVA is a professor in the Department of International and Global Studies and University Studies at Portland State University. Her research interests focus on the Ottoman and post-Ottoman Balkans: trade, nationalism, gender, public health, and General Education.

\section{NOTES}

I wish to thank my students-always a source of inspiration. I am grateful to my colleague Dr. Priya Kapoor, with whom I discussed an earlier draft of this article. I am also indebted to the anonymous reviewers for their insightful comments and suggestions.

1. I employ the term "entitlement" not as a legal concept referring to political and social rights but in its consumerist meaning as a right to consume.

2. I use Malala's first name because she adopted such approach in her international advocacy work.

3. Christina Lamb, the book's co-author, is a well-known foreign correspondent whose reports have covered Pakistan and Afghanistan since the late 1980 s.

4. All students gave written permission to cite from their papers. The orthography, syntax, and grammar are preserved.

\section{WORKS CITED}

Bonwell, C., \& Eison, J. (1991). Active learning: Creating excitement in the classroom. ASHE-ERIC Higher Education Report No. 1. Washington, DC: Jossey-Bass.

Cornwell, G., \& Stoddard, E. (1999). Globalizing knowledge: Connecting international and intercultural studies. Washington, DC: Association of American Colleges and Universities.

Freire, P. (1970). Pedagogy of the oppressed. (Myra Bergman Ramos, Trans.). New York: Herder and Herder. 
Geertz, C. (2005). Deep play: Notes on the Balinese cockfight. Daedalus, 134(4), 56-86.

Mills, A. (2014). Whose cultural competence?: Do the definitions apply beyond western borders?, Journal of General Education, 63(2-3), 232-236.

Said, E. (1979). Orientalism. New York: Vintage Books.

Scarry, E. (1998). The difficulty of imagining other persons. In E. Weiner(Ed.), The handbook of interethnic coexistence (pp. 40-62). New York: Continuum.

Sparke, M. (2013). Introducing globalization: Ties, tensions, and uneven integration. Oxford: Wiley-Blackwell.

Watters, A. (2013). Recentering pedagogy in an age of narcissism. Journal of General Education, 62(1), 52-66.

White, C. (1994). A model for comprehensive reform in general education: Portland State University. Journal of General Education 43(3), 168-229.

Young, I. (1990). Justice and the politics of difference. Princeton: Princeton University Press.

Yousafzai, M., with Lamb, C. (2013). I am Malala: The girl who stood up for education and was shot by the Taliban. New York: Back Bay Books. 